\title{
Designing Health Messages to Promote Social Change
}

\author{
Susan Kahlenberg*
}

This article explores course design in Health Communication as taught in an undergraduate liberal arts college setting. The course fuses social justice, public health, and health promotion techniques and orientations to encourage active learning and promote social change. The course is organized around three central areas of scholarship: (1) media systems and health related content; (2) health promotion; and (3) curriculum design. A variety of theoretical, methodological, and pedagogical practices are examined to demonstrate how course-learning goals are achieved. A case study of the conceptualization, design, and implementation of a public information campaign on social smoking is also introduced. [Article copies available for a fee from The Transformative Studies Institute. E-mail address: journal@transformativestudies.org Website: http://www.transformativestudies.org (C2012 by The Transformative Studies Institute. All rights reserved.]

KEYWORDS: Health Communication, Social Justice, Campaigns, Health Promotion.

\section{INTRODUCTION}

The following article explores course design of Health Communication, a course taught in an undergraduate liberal arts college, satisfying both communication major and public health minor course requirements. The

\footnotetext{
* Susan Kahlenberg, Ph.D., is Associate Professor of Media and Communication, Muhlenberg College. She explores how media messages are produced, the types of images that are represented in the media, and the impact of these messages. Her research examines characterizations on fictionally based television programming and daytime TV commercials, to deduce the extent that indices of power such as gender, occupation, intelligence, as examples, may serve to sustain the social order. Her current research projects investigate gender and brand identity in toy commercials airing on the Nickelodeon cable network. She has also studied the salience of designing health messages from social justice and public health orientations. Address correspondence to: Susan Kahlenberg, Muhlenberg College, 2400 Chew Street, Allentown, PA 18104; e-mail: skahlenb@muhlenberg.edu.
} 